\title{
Geochemical and Sr-Nd-Ca isotopic study on Nagaland Ophiolites, India plume influence on Neo-Tethyan Oceanic Lithospheric Mantle
}

\author{
SURAJ SINGH CHAUHAN ${ }^{1}$, MHABEMO ODYUO ${ }^{2}$ AND \\ RAMANANDA CHAKRABARTI ${ }^{3}$ \\ ${ }^{1}$ Indian Institute of Science \\ ${ }^{2}$ Model Christian College \\ ${ }^{3}$ Indian Institute of Science, Bangalore \\ Presenting Author: surajc@iisc.ac.in
}

The Nagaland-Manipur Ophiolites, located in the northeastern margin of India and forming a part of Indo-Myanmar Range, represents the obducted Neo-Tethyan lithospheric mantle with emplacement age estimates ranging from 116-127 Ma ago [1-2]. Petrogenetic studies of these ophiolites samples from either Nagaland or Manipur have suggested diverse origins ranging from supra-subduction zone, back-arc to MOR settings [3-5]. To further evaluate the petrogenesis of these rocks, we analysed geochemical and $\mathrm{Nd}-\mathrm{Sr}-\mathrm{Ca}$ isotopic composition of mafic rocks collected from Nagaland Hill Ophiolite (NHO) using quadrupole ICPMS and TIMS, respectively. The rocks show depleted to dominantly flat REE patterns in chondrite-normalized plots $\left(\mathrm{La} / \mathrm{Sm}_{(\mathrm{N})}=0.53\right.$ to 0.91$)$, which are higher than average $\mathrm{N}$ $\operatorname{MORB}\left(\mathrm{La} / \mathrm{Sm}_{(\mathrm{N})}=0.51\right)$ [6], and a N-MORB to E-MORB-like composition in a $\mathrm{Th}-\mathrm{Yb}-\mathrm{Nb}$ discrimation diagram. The measured ${ }^{87} \mathrm{Sr} /{ }^{86} \mathrm{Sr}(0.704999-0.706661)$ and ${ }^{143} \mathrm{Nd} /{ }^{144} \mathrm{Nd}(0.512370$ $0.512966)$ also suggests enrichment of the mantle source of these rocks. In $\mathrm{Ce} / \mathrm{Nb}$ versus $\mathrm{Th} / \mathrm{Nb}$ and $\mathrm{Nb} / \mathrm{Y}$ versus $\mathrm{Zr} / \mathrm{Y}$ discrimination diagrams, the compositions of the NHO mafic rocks overlap with basalts derived by melting of the Kerguelen plume [7]. Initial $\mathrm{Nd}$ and $\mathrm{Sr}$ isotopic compositions calculated at $117 \mathrm{Ma}$, also overlap with those of $117 \mathrm{Ma}$ old Kerguelen plume-derived basalts from north-east India [8]. The $\delta^{44 / 40} \mathrm{Ca}_{\text {SRM915a }}$ values for the mafic rocks range from 0.78 $1.11 \%$ while the associated ultramafic rocks show higher values (1.09-1.32\%o). The $\delta^{44 / 40} \mathrm{Ca}_{\mathrm{SRM} 915 \mathrm{a}}$ values show moderate correlations with $\mathrm{Mg} \#$ and $\mathrm{Mg}$ and $\mathrm{Fe}$ contents thereby suggesting the influence of magmatic processes on the $\mathrm{Ca}$ isotopic compositions of these rocks. The role of seawater alteration on the $\mathrm{Ca}$ isotopic composition of the ophiolites needs further evaluation.

[1] Singh et al., 2013 JGSL 174 (170-179); [2] Liu et al., 2016a Geology, 44, 311-314; [3] Kingson et al., 2019 GSL 481(195-210) [4] Ghosh et al., 2018, JAES 160 (67-77), [5] Khogenkumar et al., 2016, JAES, 116 (42-58) [6] Workman et al., 2005 EPSL 231(53-72); [7] Ghatak and Basu, 2013,GCA, 115 (46-72); [8] Ghatak and Basu, 2011, EPSL, 308 (52-64). 